Check for updates

Cite this: Chem. Sci., 2019, 10, 1285

๑ All publication charges for this article have been paid for by the Royal Society of Chemistry

Received 24th September 2018 Accepted 3rd December 2018

DOI: $10.1039 / c 8 s c 04242 j$

rsc.li/chemical-science

\section{Monitoring mitochondrial viscosity with anticancer phosphorescent Ir(III) complexes via two-photon lifetime imaging $\dagger$}

\author{
Liang Hao, Zhi-Wei Li, Dong-Yang Zhang, Liang He, Wenting Liu, Jing Yang, \\ Cai-Ping Tan, ${ }^{*}$ Liang-Nian Ji and Zong-Wan Mao (D) *
}

Precise quantitative measurement of viscosity at the subcellular level presents great challenges. Twophoton phosphorescence lifetime imaging microscopy (TPPLIM) can reflect micro-environmental changes of a chromophore in a quantitative manner. Phosphorescent iridium complexes are potential TPPLIM probes due to their rich photophysical properties including environment-sensitive longlifetime emission and high two-photon absorption (TPA) properties. In this work, a series of iridium(III) complexes containing rotatable groups are developed as mitochondria-targeting anticancer agents and quantitative viscosity probes. Among them, Ir6 ([Ir(ppy-CHO) 2 (dppe)]PF $;$; ppy-CHO: 4-(2-pyridyl) benzaldehyde; dppe: cis-1,2-bis(diphenylphosphino)ethene) shows satisfactory TPA properties and long lifetimes (up to $1 \mu \mathrm{s}$ ). The emission intensities and lifetimes of Ir6 are viscosity-dependent, which is mainly attributed to the configurational changes in the diphosphine ligand as proved by ${ }^{1} \mathrm{H} N M R$ spectra. Ir6 displays potent cytotoxicity, and mechanism investigations show that it can accumulate in mitochondria and induce apoptotic cell death. Moreover, Ir6 can induce mitochondrial dysfunction and monitor the changes in mitochondrial viscosity simultaneously in a real-time and quantitative manner via TPPLIM. Upon Ir6 treatment, a time-dependent increase in viscosity and heterogeneity is observed along with the loss of membrane potential in mitochondria. In summary, our work shows that multifunctional phosphorescent metal complexes can induce and precisely detect microenvironmental changes simultaneously at the subcellular level using TPPLIM, which may deepen the understanding of the cell death mechanisms induced by these metallocompounds.

\section{Introduction}

Recently, organometallic iridium complexes have been reported to exhibit potent anticancer effects. ${ }^{1}$ On the other hand, phosphorescent iridium complexes have been widely investigated for bioimaging and biosensing due to their superior photophysical properties, e.g., high quantum yields, large Stokes shifts and long emission lifetimes. ${ }^{2}$ Moreover, the phosphorescence of iridium complexes is reported to be sensitive to the environmental changes, such as oxygen, ${ }^{3}$ viscosity ${ }^{4}$ and $\mathrm{pH}^{5}{ }^{5}$ By careful structural tuning and molecular design, iridium complexes can locate in specific cell organelles to achieve bioimaging applications at the subcellular levels. ${ }^{6}$

MOE Key Laboratory of Bioinorganic and Synthetic Chemistry, School of Chemistry, Sun Yat-Sen University, Guangzhou 510275, China. E-mail: cesmzw@mail.sysu.edu. cn; tancaip@mail.sysu.edu.cn

$\dagger$ Electronic supplementary information (ESI) available: Experimental procedures, scheme, figures, tables and Movie S1. CCDC 1839168-1839170. For ESI and crystallographic data in CIF or other electronic format see DOI: 10.1039/c8sc04242j
The fluorescence lifetime of a fluorophore depends on its molecular environment but not concentration, and fluorescence lifetime imaging (FLIM) can reflect the alterations in microenvironments with high accuracy. ${ }^{7}$ In the FLIM technique, molecular rotors with viscosity-dependent lifetimes can map cellular viscosity quantitatively. ${ }^{\mathbf{8} 9}$ Most of the FLIM probes have nanosecond lifetimes similar to cellular background autofluorescence (usually below $10 \mathrm{~ns}$ ), which limits their contrast and sensitivity. Owing to their high spin-orbit coupling associated with the heavy metal ion, metal complexes are ideal candidates for phosphorescence lifetime imaging microscopy (PLIM) with emission lifetimes up to microseconds. ${ }^{\mathbf{1 0 - 1 2}}$ The accuracy can be increased due to the expanded linear correlation scope and totally depleted background emission by imposing a time delay between excitation and detection. ${ }^{\mathbf{1 3}}$ Moreover, two-photon phosphorescence lifetime imaging microscopy (TPPLIM) that uses excitation by the near-infrared (NIR) light with deep penetration depth offers the possibility of eliminating the background fluorescence effectively and reflects micro-environmental changes of the chromophore in a quantitative manner. ${ }^{\mathbf{1 0 - 1 2}}$ On the other hand, anticancer fluorescent agents that can induce and monitor therapeutic effects 
in real-time have attracted much attention as they can avoid the interference between drugs and probes. ${ }^{14}$ These anticancer agents that can reflect the changes in the microenvironment of subcellular organelles are highly desirable as they can give more insight into the mechanism investigation. ${ }^{15}$

The mitochondrion is the energy factory and a key regulator of cell death signaling. ${ }^{16}$ Intracellular viscosity affects proteinprotein interactions in cellular membranes, ${ }^{17}$ and it has been demonstrated to be associated with many diseases, e.g., atherosclerosis, ${ }^{18}$ diabetes ${ }^{19}$ and Alzheimer's disease. ${ }^{20}$ Furthermore, the viscosity in the mitochondrial matrix is closely related to mitochondrial network organization, mitochondrial respiration, metabolite diffusion and mitochondrial metabolism..$^{17,21,22}$ Recently, some fluorescent molecular rotors featuring intramolecular rotational dynamics have been designed to sense intracellular viscosity. They usually have low quantum yields due to the internal rotation, while the fluorescence recovers as the viscosity increases and the rotation gets restricted. ${ }^{\mathbf{8 , 9 2 1 - 2 3}}$ Quantitative measurement of viscosity can be achieved using ratiometric viscosity monitors with both viscosity-dependent and -independent emissive bands. ${ }^{9,21}$ Moreover, viscosity probes for specific organelles are also accomplished by introducing targeting groups. ${ }^{22,24}$

Subcellular viscosity probes with long lifetimes up to microseconds suitable for TPPLIM remain undeveloped. Iridium complexes containing phosphine ligands are widely explored as catalysts ${ }^{25}$ and phosphorescent materials, ${ }^{26,27}$ while their bioimaging or therapeutic properties are barely revealed. In this work, we introduce rotational groups into the emissive iridium complexes that can aggregate in mitochondria due to their lipophilic and cationic characteristics. As these complexes possess viscosity-sensitive two-photon absorption (TPA) properties and long emission lifetimes, we anticipate that they can reflect the changes in the subcellular microenvironments more precisely when they are performing the anticancer functions. Herein, six phosphorescent cyclometalated Ir(III) complexes Ir1Ir6 with the general formula $\left[\operatorname{Ir}(\mathrm{C}-\mathrm{N})_{2}(\mathrm{P}-\mathrm{P})\right] \mathrm{PF}_{6}(\mathrm{C}-\mathrm{N}=2$-phenylpyridine (Ir1-Ir3) or 4-(2-pyridyl)benzaldehyde (Ir4-Ir6); P-P $=$ bis-(diphenylphosphino)methane ( $\mathbf{L}_{\mathbf{1}}$ in Ir1 and Ir4), bis(diphenylphosphino)ethane ( $\mathbf{L}_{2}$ in $\mathbf{I r} \mathbf{2}$ and Ir5) or bis-(diphenylphosphino)ethylene ( $\mathbf{L}_{\mathbf{3}}$ in Ir3 and Ir6); Fig. 1a) were developed as mitochondria-targeting anticancer viscosity probes. Ir1-Ir6 contain diphosphine ligands with rotatable phenyl substitutions, and the cyclometalated ligands in Ir4-Ir6 also contain a rotatable aldehyde group. ${ }^{9,28}$ Among them, Ir6 displays high TPA properties and competent viscosity sensitivity. We demonstrate that Ir6 can localize to mitochondria and induce mitochondrial dysfunction leading to apoptotic cell death. At the same time, Ir6 can monitor the changes in mitochondrial viscosity quantitatively in a real-time manner using TPPLIM. We find that the viscosity of dysfunctional mitochondria is significantly increased in a heterogeneous fashion. In conclusion, our work demonstrates the potential of phosphorescent anticancer metallocompounds in inducing and accurately revealing microenvironmental changes at the subcellular levels. a
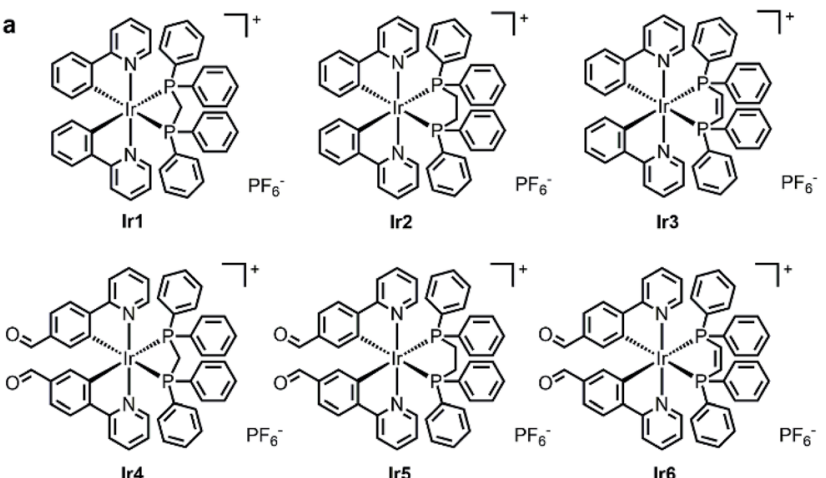

Ir4
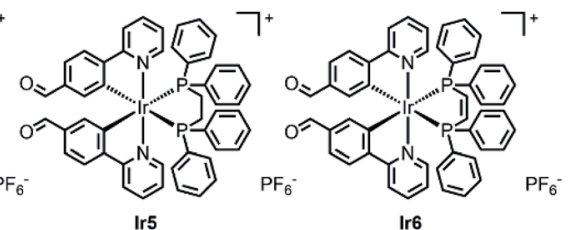

b

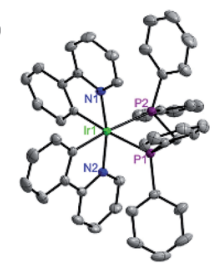

Ir1

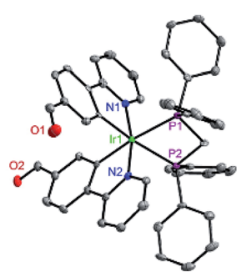

Ir4

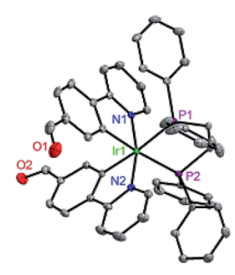

Ir6
Fig. 1 (a) Chemical structures of Ir1-Ir6. (b) X-ray crystal structures of Ir1, Ir4 and Ir6 with thermal ellipsoids set at $30 \%$ probability. The $\mathrm{H}$ atoms, counterions, and solvent molecules are omitted for clarity.

\section{Results and discussion}

\section{Synthesis and characterization}

Ir1-Ir3 were synthesized using literature methods ${ }^{27}$ and Ir4-Ir6 were obtained similarly (Scheme S1 $\dagger$ ). Briefly, two equivalents of the bis-diphenylphosphine ligand and the corresponding cyclometalated $\mathrm{Ir}(\mathrm{III})$ dimer were refluxed in $\mathrm{CH}_{2} \mathrm{Cl}_{2}-\mathrm{CH}_{3} \mathrm{OH}$ for $6 \mathrm{~h}$ (Ir1-Ir3) or in dimethylformamide for $72 \mathrm{~h}$ (Ir4-Ir6), followed by anion exchange with $\mathrm{NH}_{4} \mathrm{PF}_{6}$, purification by column chromatography and recrystallization. The complexes were characterized by ESI-MS (Fig. S1-S6†), ${ }^{1} \mathrm{H}$ NMR spectroscopy (Fig. S7-S12 $\dagger$ ) and elemental analysis. Ir1-Ir6 were stable for at least 3 days as measured in a mixed solvent of dimethyl sulfoxide- $d_{6} \quad\left(\right.$ DMSO- $\left.d_{6}\right)$ and $\mathrm{D}_{2} \mathrm{O}$ by ${ }^{1} \mathrm{H}$ NMR spectroscopy (Fig. S13 $\dagger$ ). Ir1, Ir4 and Ir6 were also characterized by X-ray crystal diffraction (Fig. $1 \mathrm{~b}$ and Table $\mathrm{S} 1 \dagger$ ). The iridium centers in Ir1, Ir4 and Ir6 adopt a distorted octahedral geometry with the two nitrogen atoms of the $\mathrm{C}-\mathrm{N}$ ligands being trans to each other. The two phosphorus atoms of the $\mathrm{P}-\mathrm{P}$ ligand are trans to the carbon atoms of the $\mathrm{C}-\mathrm{N}$ ligands.

In $\mathrm{CH}_{2} \mathrm{Cl}_{2}, \mathrm{CH}_{3} \mathrm{CN}$ and PBS at $298 \mathrm{~K}$, Ir1-Ir6 show intense absorption bands at 250-340 $\mathrm{nm}$ assigned to spin-allowed intraligand $\left({ }^{1} \mathrm{IL}\right)$ transitions and less intense absorption bands at 350-480 nm assigned to a mixture of spin-allowed and spinforbidden metal-to-ligand charge transfer transitions $\left({ }^{1} \mathrm{MLCT} /{ }^{3} \mathrm{MLCT}\right.$ ) (Fig. S14 $\left.\dagger\right) .{ }^{27}$ Upon excitation at $405 \mathrm{~nm}$, Ir1-Ir3 exhibit weak luminescence with the maxima at $c a .480 \mathrm{~nm}$, which is consistent with literature reports. ${ }^{27}$ When bulky aldehyde groups are introduced into the $\mathrm{C}-\mathrm{N}$ ligands, Ir4-Ir6 display much stronger emission at ca. $550 \mathrm{~nm}$ and longer lifetimes (up to $1 \mu \mathrm{s})$ compared with Ir1-Ir3 (ESI, Table S3†). 


\section{Viscosity-sensitive emission properties}

The emission responses of Ir1-Ir6 to viscosity were measured in mixed methanol-glycerol solvents representing different viscosities. Ir1-Ir6 exhibit viscosity-dependent phosphorescence intensities and lifetimes (Fig. 2a-c; S15 and S16 ${ }^{\dagger}$ ), which may be attributed to the rotatable aromatic rings on diphosphine ligands and aldehyde groups. ${ }^{9,28}$ The impact of viscosity on emission properties is more pronounced for Ir4-Ir6 than that observed for Ir1-Ir3. For example, the maximum emission intensity of Ir6 is enhanced by $c a$. 6.4-fold in 90\% glycerol compared with that measured in methanol, which can be easily observed by the naked eye (Fig. $2 \mathrm{a}$ and b). The lifetime of Ir6 increases from $0.54 \mu \mathrm{s}$ to $2.17 \mu \mathrm{s}$ as the viscosity increases from $0.55 \mathrm{cP}$ (centipoise) to $259 \mathrm{cP}$. A linear correlation is obtained between the lifetimes $(\log \tau)$ of Ir6 and solvent viscosity parameters (Fig. 2c), and the linear detection range coincides with the range of cellular viscosities reported., ${ }^{\mathbf{9} 21,22,24}$

To elucidate the relationship between structural restriction and viscosity-responsive emission, we measured the temperature-dependent NMR spectra and emission (Fig. 2d-f and $\mathrm{S} 17 \dagger)$. Interestingly, a linear correlation is obtained between the lifetime $(\log \tau)$ of Ir6 and temperature (K), which shows that restricting molecular rotation by reducing the temperature can increase the emission lifetime of Ir6. In NMR spectra, three kinds of $\mathrm{H}$ atoms are assigned on the dppe ligand: group $\mathrm{i}$ is from the $\mathrm{C}=\mathrm{C}$ double bond, and groups ii and iii are on the benzene rings (Fig. 2d). From the ${ }^{1} \mathrm{H}$ NMR spectra measured at different temperatures, it can be seen that the chemical shifts as well as the shape and width of the peaks assigned to these $\mathrm{H}$ atoms have changed, which indicates that the chemical environments of these $\mathrm{H}$ atoms are affected by restricted rotation. Furthermore, the ${ }^{1} \mathrm{H}-{ }^{1} \mathrm{H}$ NOESY spectra indicate that the interactions between the $\mathrm{H}$ atoms of group ii/ iii and group i become stronger as the temperature decreases, which implies that the distances between these $\mathrm{H}$ atoms are reduced at lower temperature. In summary, these results show that the viscosity-dependent emission of Ir6 may partially be attributed to the alterations in molecular configurations under restricted environments.

In order to confirm the specificity of the emission response of complexes towards viscosity, we also tested the influence of other factors on the lifetime of Ir6. The lifetime of Ir6 exhibits small response to polarity, solvent type, glutathione and human serum albumin (HSA), indicating its selectivity for viscosity (Fig. S18-S20†).

The two-photon absorption (TPA) cross-sections of Ir6 were determined using rhodamine $6 \mathrm{G}$ as the reference (Table S3 and Fig. S21 $\dagger){ }^{29}$ The maximum TPA cross-section $\left(\delta_{\max }, \lambda_{\mathrm{ex}}=\right.$ $750 \mathrm{~nm}$ ) was measured to be $444 \mathrm{GM}$, which is comparable to the TPA cross-sections reported for other two-photon phosphorescent iridium probes., ${ }^{5,30-32}$

\section{Cytotoxicities, cellular uptake and localization}

The in vitro cytotoxicities of Ir1-Ir6 and cisplatin were evaluated in A549 (human lung adenocarcinoma), HeLa (human cervical carcinoma) and LO2 (human hepatic) cells after $48 \mathrm{~h}$ treatment
(Table S4 $\dagger$ ). Generally, the order of in vitro antiproliferative activity of the compounds can be considered as Ir3 $>$ Ir1 $>$ Ir2 $>$ Ir6 > Ir4 > Ir5 > cisplatin.

Due to their intrinsic emission, we can observe the cellular uptake and localization of phosphorescent iridium complexes by confocal microscopy, which is closely related to their anticancer mechanisms. Ir1-Ir3 with low quantum yields exhibit no obvious cellular emission, and the green phosphorescence of Ir4-Ir6 is mainly maintained in the cytoplasm of A549 cells after $1 \mathrm{~h}$ incubation (Fig. S22 $\dagger$ ). Inductively coupled plasma mass spectrometry (ICP-MS) measurement shows that Ir1-Ir6 tend to accumulate in the mitochondria of A549 cells (Fig. 3a).

As Ir6 displays appropriate cytotoxicity and the best linear response to viscosity, we choose it as a model compound in the subsequent investigations.

A high colocalization is observed for Ir6 and Mito-Tracker Deep Red (MTDR), which is consistent with the results obtained by ICP-MS. Moreover, the Pearson's colocalization coefficient obtained for Ir6 with MTDR (0.93) is much higher than that obtained for Ir6 with Lyso-Tracker Deep Red (LTDR, 0.28), which further confirms that Ir6 can be used for specifically imaging mitochondria (Fig. 3b).

\section{Induction of apoptotic cell death}

Cell death can occur through various pathways (e.g., apoptosis and necrosis) that are characterized by defined morphological alterations and biochemical hallmarks. ${ }^{33}$ The cell death modes induced by Ir6 were first investigated by morphological observations. Control cells exhibit normal morphology with a plump and homogeneous nuclear staining pattern (Fig. S23†). Cells treated with Ir6 display typical morphological apoptotic characteristics including cell shrinkage, membrane blebbing, condensed chromatin, and brightly stained and fragmented nuclei. ${ }^{34}$ Transmission electron microscopy (TEM) also shows that Ir6-treated cells exhibit typical apoptotic characteristics, such as hyperchromatin and vacuolar degeneration (Fig. 3c). From the TEM picture, we can also see that Ir6-treatment causes abnormal mitochondrial morphology. In the untreated cells, normal mitochondria show a normal tubular structure. In the cells treated with Ir6, the normal shape of mitochondria disappears and mitochondria with disrupted cristae can be observed.

The externalization of phosphatidylserine (PS) on the outer leaflet of the cells is an indication of early apoptosis. ${ }^{35}$ Annexin V staining shows a concentration-dependent increase in the proportion of apoptotic cells in Ir6-treated cells, and apoptotic cells increase from $4.79 \pm 0.1 \%$ to $38.0 \pm 1.4 \%$ after Ir6 $(20 \mu \mathrm{M}, 24 \mathrm{~h})$ treatment (Fig. S24†). Confocal microscopic observation also shows that after Ir6 ( $5 \mu \mathrm{M}, 24 \mathrm{~h})$ treatment, the proportions of cells at both early (annexin V-positive and propidium iodide (PI)-negative) and late (annexin V- and PIpositive) stages of apoptosis are increased significantly (Fig. S25 $\dagger$ ). Compared with the control cells, treatment of Ir6 (10 $\mu \mathrm{M}, 6 \mathrm{~h}$ ) causes up to 2.4 -fold increases in caspase-3/7 activity in A549 cells (Fig. S26†). These results indicate that Ir6 induces caspase-mediated apoptotic cell death. 

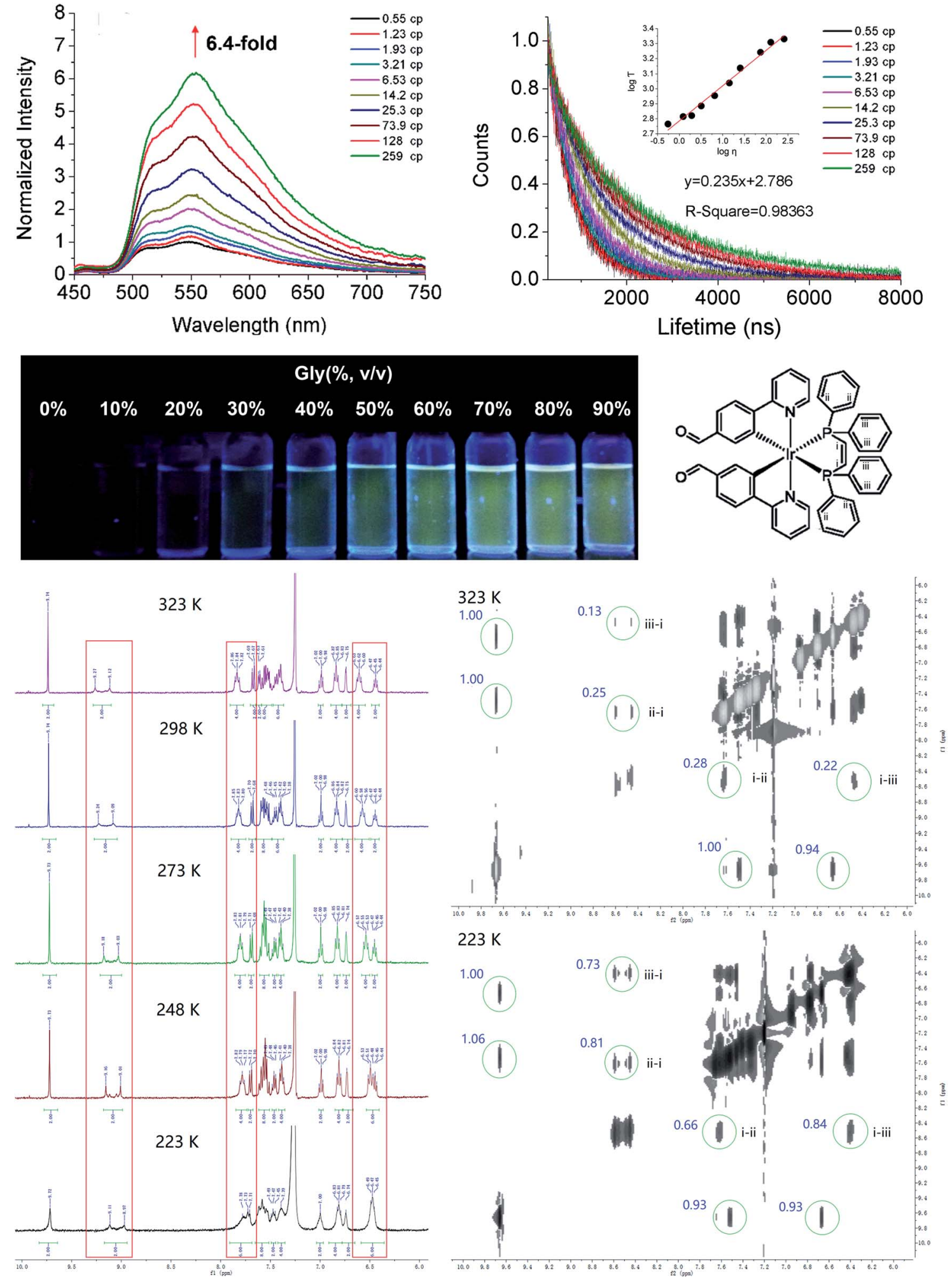

Fig. 2 (a and b) Emission intensity and (c) lifetime of Ir6 (20 $\mu \mathrm{M}$ ) in mixtures of $\mathrm{CH}_{3} \mathrm{OH}$ and glycerol (percentage of glycerol =0\%, 10\%, 20\%, 30\%, $40 \%, 50 \%, 60 \%, 70 \%, 80 \%$, and $90 \%$, v/v). The calculated viscosity parameters are indicated. $\lambda_{\text {ex }}=405 \mathrm{~nm}$. (d) To analyze the temperaturedependent NMR spectra of Ir6, three kinds of $\mathrm{H}$ atoms are assigned on the dppe ligand: group (i) is from the $\mathrm{C}=\mathrm{C}$ double bond, and groups (ii) and (iii) are on the benzene rings. (e) ${ }^{1} \mathrm{H}$ NMR spectra of Ir6 in $\mathrm{CDCl}_{3}$ at different temperatures. (f) ${ }^{1} \mathrm{H}-{ }^{1} \mathrm{H} \mathrm{NOESY}_{\text {spectra of }}$ Ir6 in $\mathrm{CDCl}$ at different temperatures. The integrals of the peaks showing the interactions between (i) and (ii)/(iii) are marked in blue. 
a

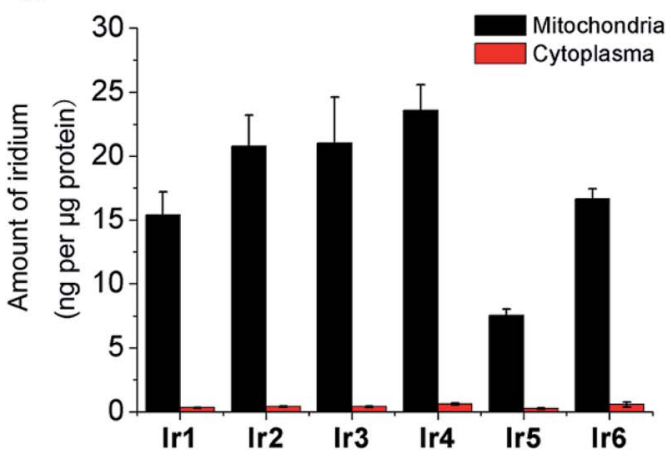

b
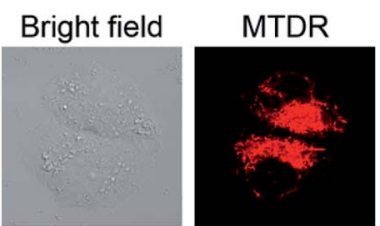

Bright field

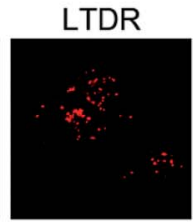

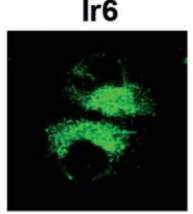

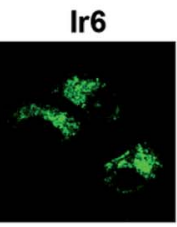

Overlay 1
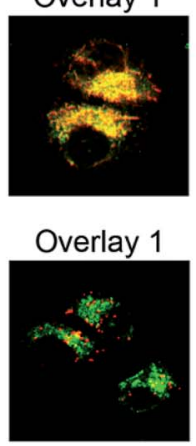

Overlay 2

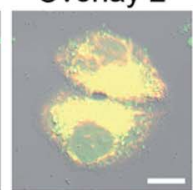

Overlay 2

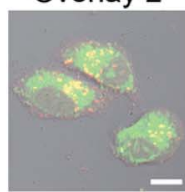

C

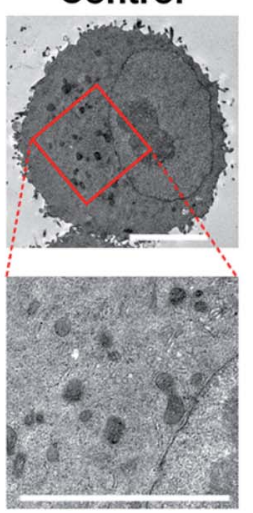

Ir6
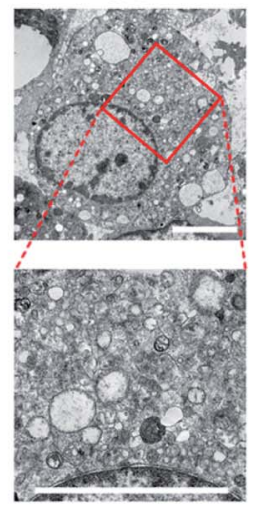

d
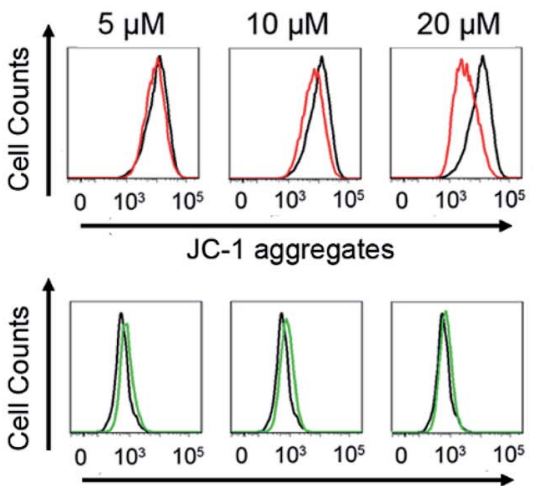

e

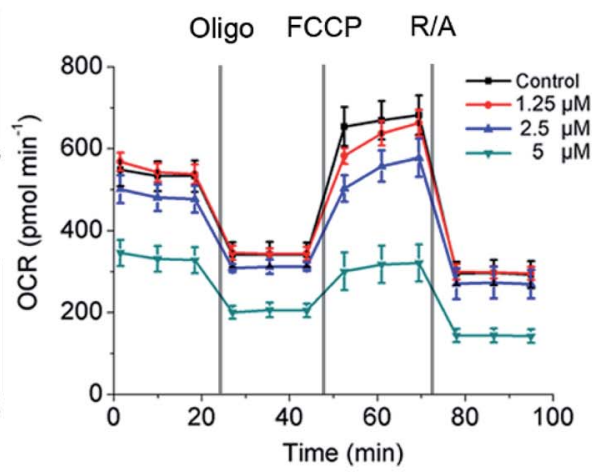

Fig. 3 (a) Detection of iridium in the extracts of A549 cells treated with Ir1-Ir6 (20 $\mu$ M, 1 h). (b) Cellular colocalization microscopy image of A549 cells incubated with Ir6 (20 $\mu$ M, $1 \mathrm{~h}$ ) and MTDR/LTDR (200 nM, $30 \mathrm{~min}) . \lambda_{\mathrm{ex}}=405 \mathrm{~nm}$ (Ir6)/633 nm (MTDR/LTDR); $\lambda_{\mathrm{em}}=550 \pm 20 \mathrm{~nm}$ (Ir6)/665 \pm $20 \mathrm{~nm}$ (MTDR/LTDR). Overlay 1: overlay of the $2 \mathrm{nd}$ and 3rd columns. Overlay 2: overlay of the 1st and 4 th columns. Scale bars: $10 \mu \mathrm{m}$. (c) TEM images of A549 cells incubated with Ir6 (20 $\mathrm{M}, 24 \mathrm{~h})$. The images in the lower panel are the enlarged images from the red boxes. Scale bars: $5 \mu \mathrm{m}$. (d) Representative result of MMP detection by JC-1 staining and flow cytometry. A549 cells were treated with Ir6 at indicated concentrations for $4 \mathrm{~h}$. $\lambda_{\mathrm{ex}}=488 \mathrm{~nm}$; $\lambda_{\mathrm{em}}=527 \pm 20 \mathrm{~nm}$ (JC-1 monomers) and $590 \pm 20 \mathrm{~nm}$ (JC-1 aggregates). The black and colored lines represent the control and Ir6-treated samples, respectively. (e) Respiratory profiles of A549 cells treated with Ir6 ( $3 \mathrm{~h}$ ) under basal conditions, and after the addition of oligomycin (Oligo, $0.75 \mu \mathrm{M})$, trifluoromethoxy carbonylcyanide phenylhydrazone (FCCP, $1.0 \mu \mathrm{M})$ and rotenone/antimycin $\mathrm{A}(\mathrm{R} / \mathrm{A}$, $0.5 \mu \mathrm{M}$ each) measured by a Seahorse XF24 Extracellular Flux Analyzer.

To further investigate the cancer cell selectivity of Ir6, we compared the anticancer activities of Ir6 on human hepatoblastoma cells (HepG2) and LO2 cells from the same organ. A higher cytotoxicity of Ir6 is observed in HepG2 cells than in LO2 cells at all the doses tested (Fig. S27a $\dagger$ ). Higher iridium levels are detected in mitochondria isolated from HepG2 cells than in mitochondria from LO2 cells, which may explain the higher cytotoxicity observed in HepG2 cells (Fig. S27b†). Furthermore, an about 1.7-fold increase in caspase-3/7 activity can be detected in HepG2 cells treated with Ir6 $(10 \mu \mathrm{M})$ while caspase-3/7 activation is not so obvious in $\mathrm{LO} 2$ cells (Fig. S27c $\dagger$ ).

\section{Induction of mitochondrial dysfunction}

As Ir6 could localize to mitochondria, we then investigated the impact of Ir6 on mitochondrial integrity. The mitochondrial membrane potential (MMP) can be measured by $5,5^{\prime}, 6,6^{\prime}$-tetrachloro-1,1'-3,3'-tetraethyl-benzimidazolylcarbocyanine iodide (JC-1) staining. At high MMPs, JC-1 exists in its aggregate form and emits red fluorescence, while it exists as a monomer and emits green fluorescence at low MMPs. ${ }^{36}$ Compared with the control group, a collapse in MMPs is observed in Ir6-treated A549 cells as indicated by the decrease in the ratio of red/green fluorescence of JC-1 (Fig. 3d and S28 $\dagger$ ). Compared with the control group, Ir6-treated cells show a significant decrease in ATP levels as measured by the CellTiter-Glo® luminescent cell viability assay (Fig. S29†). Subsequently, we used the Seahorse XF24 extracellular flux analyzer to measure the oxygen consumption rate (OCR) which is indicative of the mitochondrial oxidative phosphorylation (OXPHOS) status. ${ }^{37}$ Compared with the control cells, Ir6-treated cells display a decrease in basal respiration, ATP production and non-mitochondrial respiration, along with an increase in proton leak (Fig. 3e and S30†). These results indicate that Ir6-treatment can impair the energetic and metabolic status of mitochondria. Mitochondria are the main sites where cellular oxidative stress is produced, and defects in mitochondrial functionality often lead to the elevation of the level of ROS. ${ }^{38}$

The ROS levels were evaluated using the $2^{\prime}, 7^{\prime}$-dichlorodihydrofluorescein diacetate (DCFH-DA) assay. DCFH-DA is nonfluorescent but can be oxidized to the highly fluorescent $2^{\prime}, 7^{\prime}$ - 
dichlorofluorescein (DCF) in the presence of ROS. An obvious concentration-dependent increase in fluorescence intensity of DCF can be detected in Ir6-treated cells (Fig. S31†). Compared with the control cells, a $c a$. 34.9-fold increase in the mean fluorescence intensity (MFI) of DCF is observed in A549 cells treated with Ir6 $(20 \mu \mathrm{M}, 6 \mathrm{~h})$. Moreover, the fluorescence of DCF colocalizes well with that of the mitochondria-specific dye MTDR, which indicates that ROS are mainly generated in mitochondria (Fig. S32 $\dagger$ ). These results collectively indicate that Ir6 can cause mitochondrial dysfunction and a massive production of ROS.

\section{Tracking of mitochondrial viscosity via TPPLIM}

As previous experiments show, Ir6 can cause mitochondrial dysfunction, and a linear response relationship exists between its lifetime and environmental viscosity. We then use TPPLIM to track the dynamic changes in mitochondrial viscosity and investigate its correlation with mitochondrial physiological status. A time-dependent increase in the integrated phosphorescence lifetime is observed in Ir6-treated A549 cells in $4 \mathrm{~h}$ (Fig. 4a). As Ir6 can image mitochondrial viscosity, it can be applied to track the changes in mitochondrial viscosity in real time.

The average lifetime increases from about $1410 \mathrm{~ns}$ to $1792 \mathrm{~ns}$ and the viscosity of mitochondria is calculated to be varying from about $35 \mathrm{cP}$ to $100 \mathrm{cP}$, which is consistent with the viscosity parameters reported in the literature. ${ }^{22}$ Under the same conditions, the collapse in MMP in Ir6-treated A549 cells is also detected with JC-1 staining. The fluorescence ratio (green/red) is calculated to increase from 0.45 to 0.95 , indicating the loss of MMP (Fig. 4c). Interestingly, with the extension of incubation time, the decrease in the red/green fluorescence ratios of JC-1 and the increase in the calculated viscosity value show the same trend, which indicates that the changes in viscosity parameters can reflect the mitochondrial physiological status (Fig. 4d). The emission intensity and lifetime of Ir6 in A549 cells were also recorded by confocal microscopy in a real-time manner. As the incubation time increases, an obvious increase in the emission intensity and lifetime of Ir6 can be observed (Movie S1†).

It is known that the responses of different mitochondria in a cell to external stimuli are different, but the detection methods for mitochondrial heterogeneity are limited..$^{39,40} \mathrm{We}$ a
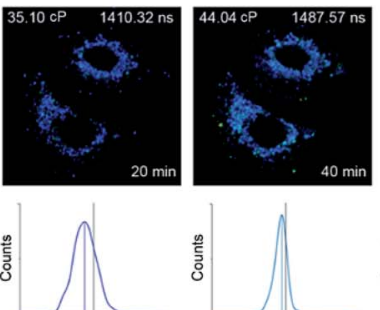

800160024003200
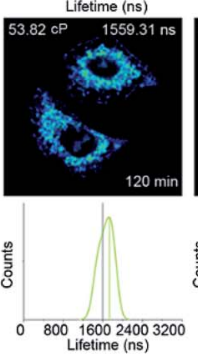

C
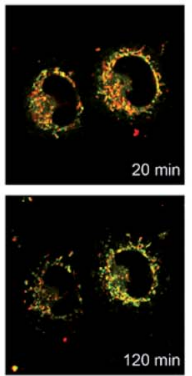
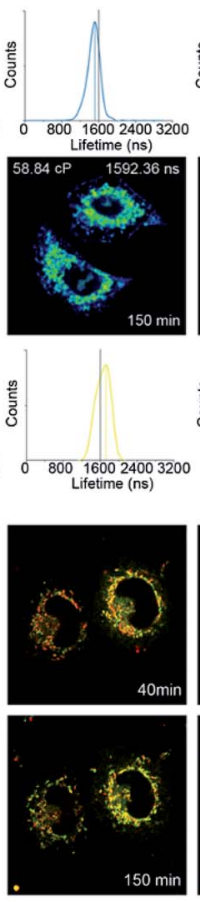
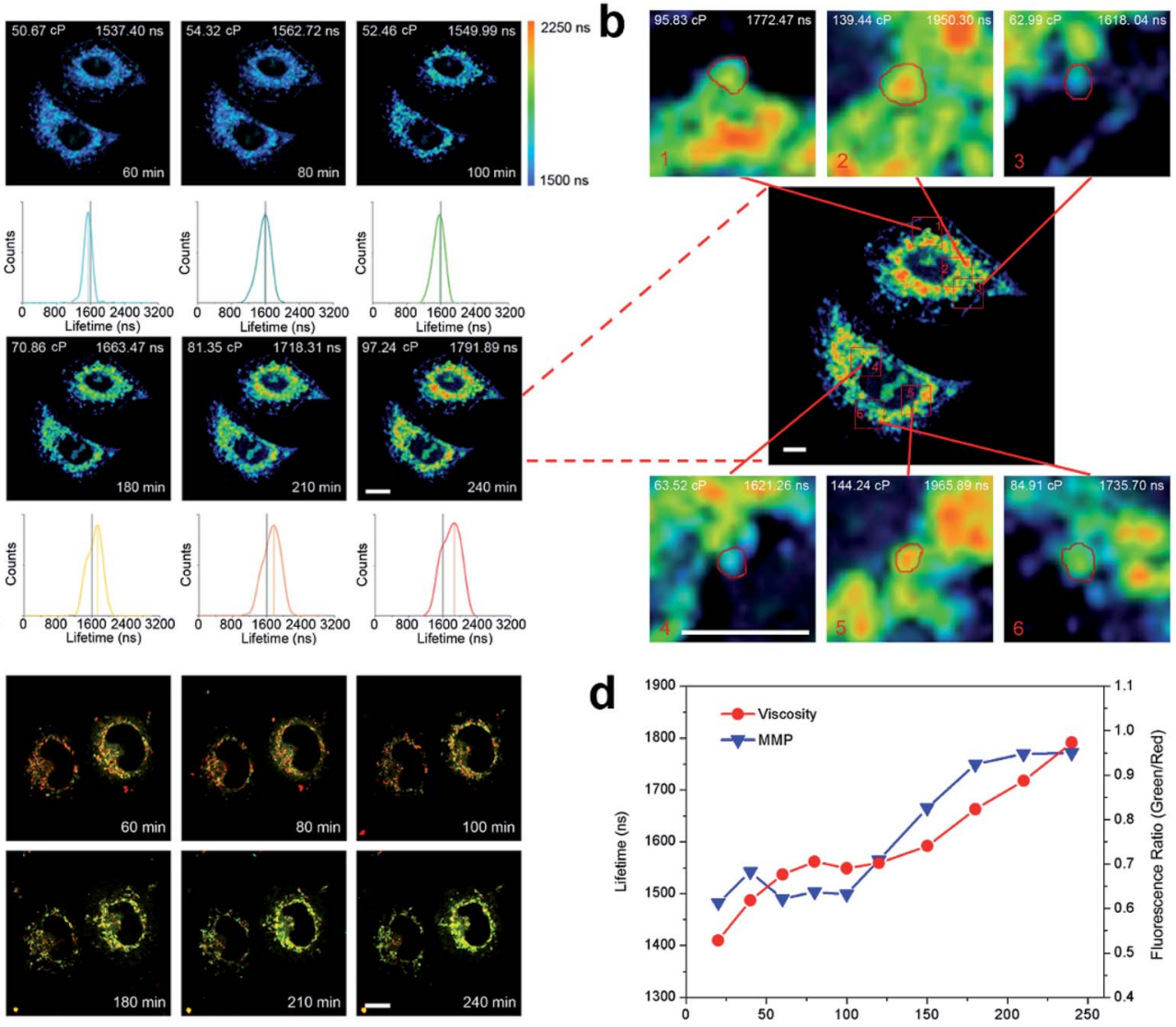
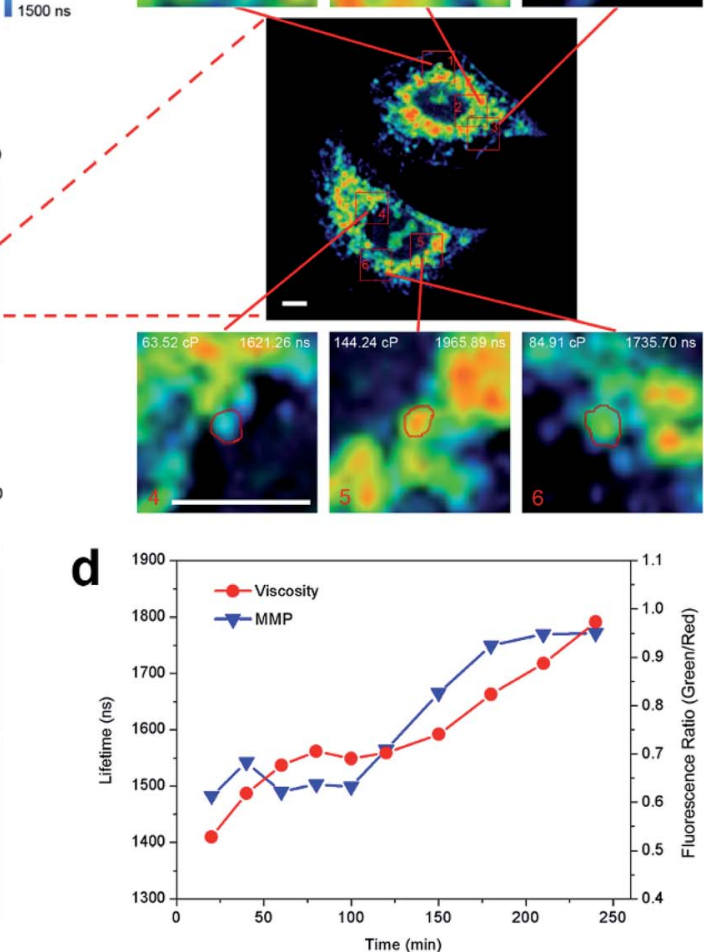

Fig. 4 (a) Mitochondrial viscosity in Ir6-treated A549 cells detected by TPPLIM. The cells were treated with Ir6 (20 $\mu$ M) and subjected to imaging at different time intervals. (b) Determination of mitochondrial heterogeneity. A549 cells were treated with Ir6 (20 $\mu$ M) for 4 h. The enlarged images are from the red boxes. The lifetime and viscosity are calculated from the spots in the red circle. $\lambda_{\mathrm{ex}}=750 \mathrm{~nm}(\mathrm{Ir} 6) ; \lambda_{\mathrm{em}}=550 \pm 20 \mathrm{~nm}$ (Ir6). (c). Confocal microscopy image of JC-1 in Ir6-treated A549 cells. $\lambda_{\mathrm{ex}}=488 \mathrm{~nm} ; \lambda_{\mathrm{em}}=530 \pm 20 \mathrm{~nm}$ (JC-1 monomers)/590 $\pm 20 \mathrm{~nm}$ (JC-1 aggregates). (d) Calculated lifetimes of Ir6 and fluorescence ratio of JC-1 (green)/J-aggregates (red). Scale bars: $10 \mu \mathrm{m}(\mathrm{a}$ and C)/5 $\mu \mathrm{m}$ (b). 
integrated the emission lifetimes of different spots in the cell and calculated the corresponding viscosity values. It can be seen that the lifetimes of different spots vary from $1618 \mathrm{~ns}$ to $1966 \mathrm{~ns}$ and the corresponding viscosity values range from $c a .63 \mathrm{cP}$ to ca. $144 \mathrm{cP}$ (Fig. 4b). The results show that TPPLIM can provide a relatively accurate quantitative method to detect mitochondrial heterogeneity.

\section{In vivo imaging of zebrafish}

Two-photon excitation imaging is attractive for in vivo applications due to the penetrability of the long wavelength photo source. Thus, we investigated the in vivo imaging capability of Ir6 using zebrafish larvae. Ir6 can effectively image zebrafish under both one- and two-photon excitation (Fig. S33†). Besides, the phosphorescence lifetimes reveal varied viscosities in different tissues of zebrafish larvae (Fig. S34†). The surface of the eyes and torso exhibits a shorter lifetime ( $c a .500 \mathrm{~ns})$. The interior of the eyes, head and spine shows a longer lifetime ( $c a$. $1300 \mathrm{~ns})$. The result demonstrates that Ir6 has potential for application in TPPLIM in vivo.

\section{Conclusions}

In this work, we designed six cyclometalated Ir(III) complexes containing diphosphine ligands as mitochondria-targeting anticancer agents. Among them, the lifetime of the Ir6 complex exhibits a specific response to the environmental viscosity and Ir6 has potent TPA properties. Ir6 can effectively accumulate in mitochondria and specifically label mitochondria. Moreover, Ir6 can induce apoptosis mediated by caspase activation. As expected, Ir6 can impair the energetic/metabolic status of mitochondria and cause massive production of mitochondrial ROS. Owing to its viscosity-responsive phosphorescence lifetimes, Ir6 is capable of monitoring the changes in mitochondrial viscosity using TPPLIM in real-time. At the same time, the heterogeneity of mitochondria can be detected during the process of damage using TPPLIM. In conclusion, our work provides a new clue for the design of small molecule-based anticancer agents that can induce and monitor therapeutic effects by quantitative detection of microenvironmental changes at the subcellular level.

\section{Experimental section}

\section{Synthetic protocol and characterization}

$\left[\mathrm{Ir}_{2}(\mathbf{p p y})_{4} \mathbf{C l}_{2}\right]$ and $\left[\mathrm{Ir}_{2}(\mathbf{p p y}-\mathbf{C H O})_{4} \mathbf{C l}_{2}\right]$. These compounds were synthesized using literature methods. ${ }^{41}$ Briefly, $\mathrm{IrCl}_{3} \cdot 3 \mathrm{H}_{2} \mathrm{O}$ $(1.00 \mathrm{~g}, 2.84 \mathrm{mmol})$ and ppy $(0.967 \mathrm{~g}, 6.25 \mathrm{mmol})$ or ppy-CHO $(1.145 \mathrm{~g}, 6.25 \mathrm{mmol})$ were refluxed in 2-ethoxyethanol $(100 \mathrm{~mL})$ for $18 \mathrm{~h}$. After cooling to room temperature and filtration, the residue was washed with methanol and ether. $\left[\mathrm{Ir}_{2}(\mathrm{ppy})_{4} \mathrm{Cl}_{2}\right]$ and $\left[\mathrm{Ir}_{2}(\text { ppy-CHO })_{4} \mathrm{Cl}_{2}\right]$ were obtained as yellow and orange solids, respectively.

$\left[\operatorname{Ir}(\mathbf{p p y})_{2} \mathbf{L}_{\mathbf{1}}\right]\left(\mathbf{P F}_{\mathbf{6}}\right) \quad$ (Ir1). Ir1 was synthesized by reacting

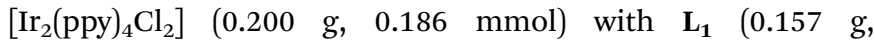
$0.410 \mathrm{mmol}$ ) according to literature methods. ${ }^{27}$ Yield: $0.299 \mathrm{~g}$
(78\%). ${ }^{1} \mathrm{H}$ NMR (400 MHz, $d_{6}$-DMSO) $\delta$ 8.11-8.02 (m, 4H; H1, 5, 16, 20), 7.89 (d, $J=7.7 \mathrm{~Hz}, 2 \mathrm{H} ; \mathrm{H} 28,29), 7.74$ (dd, $J=15.3$, $7.6 \mathrm{~Hz}, 6 \mathrm{H}$; H24, 17-19), 7.57 (t, $J=7.2 \mathrm{~Hz}, 6 \mathrm{H}$; H7-9, 12-14), $7.13(\mathrm{t}, J=7.3 \mathrm{~Hz}, 2 \mathrm{H} ; \mathrm{H} 26,31), 7.06$ (t, $J=7.4 \mathrm{~Hz}, 2 \mathrm{H} ; \mathrm{H} 23,34)$, $6.98(\mathrm{t}, J=7.5 \mathrm{~Hz}, 6 \mathrm{H} ; \mathrm{H} 21,25,32,36,24,33), 6.87$ (t, $J=8.5 \mathrm{~Hz}$, $4 \mathrm{H} ; \mathrm{H} 6,10,11,15), 6.62(\mathrm{t}, J=6.6 \mathrm{~Hz}, 2 \mathrm{H} ; \mathrm{H} 22,35), 6.30(\mathrm{~d}, J=$ $5.0 \mathrm{~Hz}, 2 \mathrm{H}$; H27, 30), 5.94 (t, $J=9.9 \mathrm{~Hz}, 2 \mathrm{H}$; H37). ESI-MS $\left(\mathrm{CH}_{3} \mathrm{OH}\right): \mathrm{m} / \mathrm{z}$ calcd for $\left[\mathrm{M}-\mathrm{PF}_{6}\right]^{+}, 885.22$; found: 885.3. Elemental analysis calcd (\%) for $\mathrm{C}_{47} \mathrm{H}_{38} \mathrm{IrN}_{2} \mathrm{P}_{3} \mathrm{~F}_{6} \cdot \mathrm{H}_{2} \mathrm{O}: \mathrm{C}, 53.87$; $\mathrm{H}, 3.85$; N, 2.67; found: C, 53.93; H, 3.78; N, 2.63.

$\left[\operatorname{Ir}(\mathbf{p p y})_{2} \mathbf{L}_{2}\right]\left(\mathbf{P F}_{\mathbf{6}}\right) \quad(\mathbf{I r} 2)$. Ir2 was synthesized by reacting $\left[\mathrm{Ir}_{2}(\mathrm{ppy})_{4} \mathrm{Cl}_{2}\right](0.200 \mathrm{~g}, 0.186 \mathrm{mmol})$ with $\mathbf{L}_{2}(0.163 \mathrm{~g}, 0.410$ $\mathrm{mmol})$ according to literature methods. ${ }^{27}$ Yield: $0.249 \mathrm{~g}(64 \%)$. ${ }^{1} \mathrm{H}$ NMR (400 MHz, $d_{6}$-DMSO) $\delta 7.94(\mathrm{~d}, J=8.2 \mathrm{~Hz}, 2 \mathrm{H} ; \mathrm{H} 1,20)$, 7.85 (d, $J=7.7 \mathrm{~Hz}, 2 \mathrm{H}$; H5, 16), 7.73 (dd, $J=15.6,7.0 \mathrm{~Hz}, 6 \mathrm{H}$; H2-4, 17-19), 7.64 (t, $J=7.7 \mathrm{~Hz}, 2 \mathrm{H}$; H28, 29), 7.47 (t, $J=7.3 \mathrm{~Hz}$, 2H; H8, 13), 7.36 (t, $J=7.3 \mathrm{~Hz}, 4 \mathrm{H} ; \mathrm{H} 7,9,12,14), 7.05(\mathrm{t}, J=$ $7.4 \mathrm{~Hz}, 4 \mathrm{H} ; \mathrm{H} 23,26,31,34), 6.96(\mathrm{t}, J=7.3 \mathrm{~Hz}, 2 \mathrm{H} ; \mathrm{H} 24,33), 6.90$ $(\mathrm{t}, J=7.4 \mathrm{~Hz}, 4 \mathrm{H} ; \mathrm{H} 21,25,32,36), 6.64(\mathrm{t}, J=8.4 \mathrm{~Hz}, 4 \mathrm{H} ; \mathrm{H6}, 10$, 11, 15), 6.47 (t, $J=6.6 \mathrm{~Hz}, 2 \mathrm{H} ; \mathrm{H} 22,35), 6.22$ (d, $J=4.6 \mathrm{~Hz}, 2 \mathrm{H}$; H27, 30), 3.92 (dt, $J=23.3,12.6 \mathrm{~Hz}, 2 \mathrm{H}$; H37, 38), 2.92 (d, $J=$ $9.3 \mathrm{~Hz}, 2 \mathrm{H} ; \mathrm{H} 37,38)$. ESI-MS $\left(\mathrm{CH}_{3} \mathrm{OH}\right): m / z$ calcd for $\left[\mathrm{M}-\mathrm{PF}_{6}\right]^{+}$, 899.23; found: 899.3. Elemental analysis calcd (\%) for $\mathrm{C}_{48} \mathrm{H}_{40^{-}}$ $\mathrm{IrN}_{2} \mathrm{P}_{3} \mathrm{~F}_{6}$ : C, 55.22; H, 3.86; N, 2.68; found: C, 54.97; H, 3.79; N, 2.59.

$\left[\operatorname{Ir}(\mathbf{p p y})_{2} \mathbf{L}_{3}\right]\left(\mathbf{P F}_{\mathbf{6}}\right)$ (Ir3). Ir3 was synthesized by reacting $\left[\operatorname{Ir}_{2}(\text { ppy })_{4} \mathrm{Cl}_{2}\right](0.200 \mathrm{~g}, 0.186 \mathrm{mmol})$ with $\mathbf{L}_{3}(0.162 \mathrm{~g}, 0.410$ $\mathrm{mmol}$ ) according to literature methods. ${ }^{27}$ Yield: $0.279 \mathrm{~g}(72 \%)$. ${ }^{1} \mathrm{H}$ NMR (400 MHz, $d_{6}$-DMSO) $\delta$ 8.97-8.76 (m, 2H; H37, 38), 7.85 (dd, $J=16.3,8.2 \mathrm{~Hz}, 6 \mathrm{H}$; H1, 5, 16, 20), 7.78 (d, $J=7.7 \mathrm{~Hz}, 2 \mathrm{H}$; $\mathrm{H} 3,18), 7.59$ (dd, $J=12.9,7.1 \mathrm{~Hz}, 4 \mathrm{H} ; \mathrm{H} 4,28,29,17), 7.50$ (t, $J=$ $7.3 \mathrm{~Hz}, 4 \mathrm{H}$; H7, 9, 12, 14), 7.42 (d, J=5.8 Hz, 2H; H8, 13), 7.07 (dd, $J=13.3,6.9 \mathrm{~Hz}, 4 \mathrm{H}$; H23, 26, 31, 34), 6.99 (t, $J=7.3 \mathrm{~Hz}, 2 \mathrm{H}$; H24, 33), 6.90 (t, J=7.1 Hz, 4H; H21, 25, 32, 36), 6.64-6.29 (m, $6 \mathrm{H}$; H6, 10, 11, 15, 2, 19), 6.20 (dd, $J=7.1,2.1 \mathrm{~Hz}, 2 \mathrm{H} ; \mathrm{H} 27,30)$. ESI-MS $\left(\mathrm{CH}_{3} \mathrm{OH}\right): m / z$ calcd for $\left[\mathrm{M}-\mathrm{PF}_{6}\right]^{+}, 897.22$; found: 897.3. Elemental analysis calcd (\%) for $\mathrm{C}_{48} \mathrm{H}_{38} \operatorname{IrN}_{2} \mathrm{P}_{3} \mathrm{~F}_{6}$ : C, 55.33; H, 3.68, N, 2.68; found: C, 54.96; H, 3.62; N, 2.64 .

$\left[\operatorname{Ir}(\mathbf{p p y}-\mathbf{C H O})_{2} \mathbf{L}_{\mathbf{1}}\right]\left(\mathbf{P F}_{\mathbf{6}}\right) \quad$ (Ir4). $\quad\left[\operatorname{Ir}_{2}(\text { ppy-CHO })_{4} \mathrm{Cl}_{2}\right] \quad(0.200 \mathrm{~g}$, $0.168 \mathrm{mmol})$ and $\mathbf{L}_{\mathbf{1}}(0.143 \mathrm{~g}, 0.372 \mathrm{mmol})$ were refluxed in dimethyl formamide for $72 \mathrm{~h}$. After cooling to room temperature, the solution was evaporated to $5 \mathrm{~mL}$ under reduced pressure before being instilled into saturated aqueous solution of $\mathrm{NH}_{4} \mathrm{PF}_{6}$. The resulting turbid liquid was filtered to obtain light yellow solids. The crude product was purified by column chromatography on silica gel $\left(\mathrm{CH}_{2} \mathrm{Cl}_{2}: \mathrm{CH}_{3} \mathrm{OH}=99: 1, \mathrm{v} / \mathrm{v}\right)$ and recrystallized by diffusion of diethyl ether into acetonitrile. The final product was obtained as yellow crystals. Yield: $0.274 \mathrm{~g}$ (75\%). ${ }^{1} \mathrm{H}$ NMR (400 MHz, $d_{6}$-DMSO) $\delta 9.74$ (s, 2H; H27, 30), 8.24 (d, $J=8.1 \mathrm{~Hz}, 2 \mathrm{H}$; H28, 29), 8.15 (dd, $J=9.1,7.5 \mathrm{~Hz}, 4 \mathrm{H} ; \mathrm{H} 1,5$, $16,20), 7.89(\mathrm{t}, J=7.7 \mathrm{~Hz}, 2 \mathrm{H} ; \mathrm{H} 3,18), 7.70$ (t, $J=8.5 \mathrm{~Hz}, 4 \mathrm{H} ; \mathrm{H} 2$, 4, 11, 19), 7.65-7.50 (m, 8H; H7-9, 12-14, 26, 31), $7.15(\mathrm{t}, J=$ $7.3 \mathrm{~Hz}, 2 \mathrm{H}), 6.99(\mathrm{t}, J=7.0 \mathrm{~Hz}, 4 \mathrm{H}), 6.84(\mathrm{dt}, J=13.5,7.9 \mathrm{~Hz}$, $6 \mathrm{H}), 6.77(\mathrm{~d}, J=2.5 \mathrm{~Hz}, 2 \mathrm{H}), 6.05(\mathrm{t}, J=10.1 \mathrm{~Hz}, 2 \mathrm{H})$. ESI-MS $\left(\mathrm{CH}_{3} \mathrm{OH}\right): \mathrm{m} / z$ calcd for $\left[\mathrm{M}-\mathrm{PF}_{6}\right]^{+}, 941.20 ;\left[\mathrm{M}-\mathrm{PF}_{6}+\right.$ $\left.\mathrm{CH}_{3} \mathrm{OH}\right]^{+}$, 973.23; $\left[\mathrm{M}-\mathrm{PF}_{6}+2 \mathrm{CH}_{3} \mathrm{OH}\right]^{+}, 1005.26$; found: 941.3, 
973.3, 1005.3. Elemental analysis calcd (\%) for $\mathrm{C}_{49} \mathrm{H}_{38} \mathrm{IrN}_{2} \mathrm{O}_{2}-$ $\mathrm{P}_{3} \mathrm{~F}_{6}$ : C, 53.73; H, 3.53; N, 2.58; found: C, 53.96; H, 3.50; N, 2.51.

$\left[\operatorname{Ir}(\mathbf{p p y}-\mathbf{C H O})_{2} \mathbf{L}_{2}\right]\left(\mathbf{P F}_{6}\right)$ (Ir5). Ir5 was synthesized adopting a similar procedure to that described for $\mathbf{I r} \mathbf{4}$ by using $\mathbf{L}_{2}$ instead of $\mathbf{L}_{\mathbf{1}}$ as the ligand. Yield: $0.225 \mathrm{~g}(61 \%) .{ }^{1} \mathrm{H}$ NMR $\left(400 \mathrm{MHz}, d_{6}\right.$ DMSO) $\delta 9.74$ (s, 2H; H27, 30), 8.17-8.07 (m, 4H; H1, 5, 16, 20), 7.80 (dd, $J=13.6,6.6 \mathrm{~Hz}, 4 \mathrm{H} ; \mathrm{H} 3,18,26,31), 7.68$ (t, $J=8.6 \mathrm{~Hz}$, $4 \mathrm{H} ; \mathrm{H} 2,4,17,19), 7.58$ (d, $J=7.9 \mathrm{~Hz}, 2 \mathrm{H} ; \mathrm{H} 28,29), 7.46$ (t, $J=$ $7.4 \mathrm{~Hz}, 2 \mathrm{H}$; H7, 13), $7.31(\mathrm{t}, J=7.1 \mathrm{~Hz}, 4 \mathrm{H} ; \mathrm{H6}, 8,12,14), 7.07(\mathrm{t}, J$ $=7.3 \mathrm{~Hz}, 2 \mathrm{H} ; \mathrm{H} 23,34), 6.91(\mathrm{t}, J=7.0 \mathrm{~Hz}, 4 \mathrm{H} ; \mathrm{H} 21,25,32,36)$, $6.72(\mathrm{~d}, J=2.8 \mathrm{~Hz}, 2 \mathrm{H} ; 24,33), 6.69-6.56$ (m, 6H; H6, 10, 11, 15, 22, 35), 3.98 (dd, $J=30.1,10.1 \mathrm{~Hz}, 2 \mathrm{H}$; H37, 38), 3.02 (d, $J=$ $9.2 \mathrm{~Hz}, 2 \mathrm{H}$; H37, 38). ESI-MS $\left(\mathrm{CH}_{3} \mathrm{OH}\right): m / z$ calcd for $\left[\mathrm{M}-\mathrm{PF}_{6}\right]^{+}$, 955.22; $\left[\mathrm{M}-\mathrm{PF}_{6}+\mathrm{CH}_{3} \mathrm{OH}\right]^{+}, 987.25 ;\left[\mathrm{M}-\mathrm{PF}_{6}+2 \mathrm{CH}_{3} \mathrm{OH}\right]^{+}$, 1019.27; found: 955.3, 987.3, 1019.3. Elemental analysis calcd (\%) for $\mathrm{C}_{50} \mathrm{H}_{40} \mathrm{IrN}_{2} \mathrm{O}_{2} \mathrm{P}_{3} \mathrm{~F}_{6} \cdot 3 \mathrm{H}_{2} \mathrm{O}: \mathrm{C}, 54.59 ; \mathrm{H}, 3.67 ; \mathrm{N}, 2.55$; found: C, 54.37; H, 3.93; N, 2.46.

$\left[\operatorname{Ir}(\text { ppy-CHO) })_{2} \mathbf{L}_{3}\right]\left(\mathbf{P F}_{\mathbf{6}}\right)$ (Ir6). Ir6 was synthesized adopting a similar procedure to that described for $\mathbf{I r} \mathbf{4}$ by using $\mathbf{L}_{3}$ instead of $\mathbf{L}_{\mathbf{1}}$ as the ligand. Yield: $0.247 \mathrm{~g}(67 \%) .{ }^{1} \mathrm{H}$ NMR $\left(400 \mathrm{MHz}, d_{6}\right.$ DMSO) $\delta 9.75$ (s, 2H; H27, 30), 8.98-8.82 (m, 2H; H37, 38), 8.03 (t, $J=7.2 \mathrm{~Hz}, 4 \mathrm{H}$; H1, 5, 16, 20), 7.78 (dt, $J=15.5,8.1 \mathrm{~Hz}, 6 \mathrm{H}$; H2-4, 17-19), 7.59 (t, $J=8.2 \mathrm{~Hz}, 4 \mathrm{H} ; \mathrm{H} 26,28,29,31), 7.48$ (dd, $J$ $=10.6,5.8 \mathrm{~Hz}, 6 \mathrm{H}$; H7-9, 12-14), 7.11 (t, $J=7.4 \mathrm{~Hz}, 2 \mathrm{H}$; H23, 34), $6.92(\mathrm{t}, J=7.1 \mathrm{~Hz}, 4 \mathrm{H} ; \mathrm{H} 21,25,32,36), 6.70-6.60(\mathrm{~m}, 4 \mathrm{H}$; H22, 24, 33, 35), 6.48 (t, $J=8.6 \mathrm{~Hz}, 4 \mathrm{H} ; \mathrm{H6}, 10,11,15)$. ESI-MS $\left(\mathrm{CH}_{3} \mathrm{OH}\right): m / z$ calcd for $\left[\mathrm{M}-\mathrm{PF}_{6}\right]^{+}, 953.20 ;\left[\mathrm{M}-\mathrm{PF}_{6}+\mathrm{CH}_{3} \mathrm{OH}\right]^{+}$, 985.23; $\left[\mathrm{M}-\mathrm{PF}_{6}+2 \mathrm{CH}_{3} \mathrm{OH}\right]^{+}, 1017.26$; found: 953.3, 985.3, 1017.4. Elemental analysis calcd (\%) for $\mathrm{C}_{50} \mathrm{H}_{38} \mathrm{IrN}_{2} \mathrm{O}_{2} \mathrm{P}_{3} \mathrm{~F}_{6}$ : C, 54.70; H, 3.49; N, 2.55; found: C, 54.26; H, 3.38; N, 2.47.

\section{Real-time tracking of mitochondria by TPPLIM}

A549 cells were seeded in $35 \mathrm{~mm}$ culture dishes (Corning) and incubated for $24 \mathrm{~h}$. The growth medium was replaced by PBS with Ir6 $(20 \mu \mathrm{M})$ and DMSO $(1 \%, \mathrm{v} / \mathrm{v})$ before visualization by confocal microscopy. The confocal microscope is connected to an incubator that provides a constant temperature $\left(37^{\circ} \mathrm{C}\right)$ and $\mathrm{CO}_{2}$ (5\%). The luminescence intensity and phosphorescence lifetime of Ir6 under two-photon excitation were collected, respectively. The phosphorescence lifetime value is given by Becker \& Hickl SPCImage. $\lambda_{\mathrm{ex}}=750 \mathrm{~nm}(\mathrm{TPM}) ; \lambda_{\mathrm{em}}=550 \pm$ $20 \mathrm{~nm}$.

\section{Conflicts of interest}

The authors declare no conflict of interest.

\section{Acknowledgements}

This study was supported by the National Natural Science Foundation of China (21778078, 21571196, 21572282 and 21837006), the 973 program (2015CB856301), the Guangdong Natural Science Foundation (2015A030306023), Innovative Research Team in University of Ministry of Education of China (IRT_17R111) and the Fundamental Research Funds for the Central Universities.

\section{Notes and references}

1 Z. Liu, I. Romero-Canelón, B. Qamar, J. M. Hearn, A. Habtemariam, N. P. E. Barry, A. M. Pizarro, G. J. Clarkson and P. J. Sadler, Angew. Chem., Int. Ed., 2014, 53, 3941-3946.

2 L. C.-C. Lee, J. C.-W. Lau, H.-W. Liu and K. K.-W. Lo, Angew. Chem., Int. Ed., 2016, 55, 1046-1049.

3 S. Zhang, M. Hosaka, T. Yoshihara, K. Negishi, Y. Iida, S. Tobita and T. Takeuchi, Cancer Res., 2010, 70, 4490.

4 F. Liu, J. Wen, S.-S. Chen and S. Sun, Chem. Commun., 2018, 54, 1371-1374.

5 L. He, C.-P. Tan, R.-R. Ye, Y.-Z. Zhao, Y.-H. Liu, Q. Zhao, L.-N. Ji and Z.-W. Mao, Angew. Chem., Int. Ed., 2014, 53, 12137-12141.

6 K. Qiu, Y. Chen, T. W. Rees, L. Ji and H. Chao, Coord. Chem. Rev., 2019, 378, 66-86.

7 M. Y. Berezin and S. Achilefu, Chem. Rev., 2010, 110, 26412684.

8 M. K. Kuimova, G. Yahioglu, J. A. Levitt and K. Suhling, J. Am. Chem. Soc., 2008, 130, 6672-6673.

9 X. Peng, Z. Yang, J. Wang, J. Fan, Y. He, F. Song, B. Wang, S. Sun, J. Qu, J. Qi and M. Yan, J. Am. Chem. Soc., 2011, 133, 6626-6635.

10 J. Wang, J. Xue, Z. Yan, S. Zhang, J. Qiao and X. Zhang, Angew. Chem., Int. Ed., 2017, 56, 14928-14932.

11 E. Baggaley, M. R. Gill, N. H. Green, D. Turton, I. V. Sazanovich, S. W. Botchway, C. Smythe, J. W. Haycock, J. A. Weinstein and J. A. Thomas, Angew. Chem., Int. Ed., 2014, 53, 3367-3371.

12 K. Y. Zhang, Q. Yu, H. Wei, S. Liu, Q. Zhao and W. Huang, Chem. Rev., 2018, 118, 1770-1839.

13 S. Liu, H. Liang, K. Y. Zhang, Q. Zhao, X. Zhou, W. Xu and W. Huang, Chem. Commun., 2015, 51, 7943-7946.

14 R. Kumar, W. S. Shin, K. Sunwoo, W. Y. Kim, S. Koo, S. Bhuniya and J. S. Kim, Chem. Soc. Rev., 2015, 44, 66706683.

15 R. Kumar, J. Han, H.-J. Lim, W. X. Ren, J.-Y. Lim, J.-H. Kim and J. S. Kim, J. Am. Chem. Soc., 2014, 136, 17836-17843.

16 S. W. G. Tait and D. R. Green, Nat. Rev. Mol. Cell Biol., 2010, 11, 621-632.

17 S. J. Singer and G. L. Nicolson, Science, 1972, 175, 720-731. 18 G. Deliconstantinos, V. Villiotou and J. C. Stavrides, Biochem. Pharmacol., 1995, 49, 1589-1600.

19 O. Nadiv, M. Shinitzky, H. Manu, D. Hecht, C. T. Roberts, D. Leroith and Y. Zick, Biochem. J., 1994, 298(2), 443-450.

20 G. S. Zubenko, U. Kopp, T. Seto and L. L. Firestone, Psychopharmacology, 1999, 145, 175-180.

21 F. Liu, T. Wu, J. Cao, S. Cui, Z. Yang, X. Qiang, S. Sun, F. Song, J. Fan, J. Wang and X. Peng, Chem.-Eur. J., 2013, 19, 1548-1553.

22 Z. Yang, Y. He, J.-H. Lee, N. Park, M. Suh, W.-S. Chae, J. Cao, X. Peng, H. Jung, C. Kang and J. S. Kim, J. Am. Chem. Soc., 2013, 135, 9181-9185.

23 M. K. Kuimova, S. W. Botchway, A. W. Parker, M. Balaz, H. A. Collins, H. L. Anderson, K. Suhling and P. R. Ogilby, Nat. Chem., 2009, 1, 69-73. 
24 L. Wang, Y. Xiao, W. Tian and L. Deng, J. Am. Chem. Soc., 2013, 135, 2903-2906.

25 T. Hayashi, Acc. Chem. Res., 2000, 33, 354-362.

26 S.-X. Luo, L. Wei, X.-H. Zhang, M. H. Lim, K. X. V. Lin, M. H. V. Yeo, W.-H. Zhang, Z.-P. Liu, D. J. Young and T. S. A. Hor, Organometallics, 2013, 32, 2908-2917.

27 D. Rota Martir, A. K. Bansal, V. Di Mascio, D. B. Cordes, A. F. Henwood, A. M. Z. Slawin, P. C. J. Kamer, L. Martínez-Sarti, A. Pertegás, H. J. Bolink, I. D. W. Samuel and E. Zysman-Colman, Inorg. Chem. Front., 2016, 3, 218235.

28 H. Zhu, J. Fan, M. Li, J. Cao, J. Wang and X. Peng, Chem.-Eur. J., 2014, 20, 4691-4696.

29 N. S. Makarov, M. Drobizhev and A. Rebane, Opt. Express, 2008, 16, 4029-4047.

30 J. Massue, J. Olesiak-Banska, E. Jeanneau, C. Aronica, K. Matczyszyn, M. Samoc, C. Monnereau and C. Andraud, Inorg. Chem., 2013, 52, 10705-10707.

31 W.-J. Xu, S.-J. Liu, X. Zhao, N. Zhao, Z.-Q. Liu, H. Xu, H. Liang, Q. Zhao, X.-Q. Yu and W. Huang, Chem.-Eur. J., 2013, 19, 621-629.

32 C. L. Ho, K. L. Wong, H. K. Kong, Y. M. Ho, C. T. L. Chan, W. M. Kwok, K. S. Y. Leung, H. L. Tam, M. H. W. Lam, X. F. Ren, A. M. Ren, J. K. Feng and W. Y. Wong, Chem. Commun., 2012, 48, 2525-2527.
33 G. Kroemer, L. Galluzzi, P. Vandenabeele, J. Abrams, E. S. Alnemri, E. H. Baehrecke, M. V. Blagosklonny, W. S. El-Deiry, P. Golstein, D. R. Green, M. Hengartner, R. A. Knight, S. Kumar, S. A. Lipton, W. Malorni, G. Nuñez, M. E. Peter, J. Tschopp, J. Yuan, M. Piacentini, B. Zhivotovsky and G. Melino, Cell Death Differ., 2008, 16, 3. 34 R. C. Taylor, S. P. Cullen and S. J. Martin, Nat. Rev. Mol. Cell Biol., 2008, 9, 231-241.

35 R. S. Hotchkiss, A. Strasser, J. E. Mcdunn and P. E. Swanson, N. Engl. J. Med., 2009, 361, 1570-1583.

36 S. T. Smiley, M. Reers, C. Mottola-Hartshorn, M. Lin, A. Chen, T. W. Smith, G. D. Steele and L. B. Chen, Proc. Natl. Acad. Sci. U. S. A., 1991, 88, 3671-3675.

37 M. B. De Moura and B. Van Houten, Methods Mol. Biol., 2014, 1105, 589-602.

38 S. S. Sabharwal and P. T. Schumacker, Nat. Rev. Cancer, 2014, 14, 709-721.

39 A. V. Kuznetsov, J. Troppmair, R. Sucher, M. Hermann, V. Saks and R. Margreiter, Biochim. Biophys. Acta, 2006, 1757, 686-691.

40 S. Salvioli, J. Dobrucki, L. Moretti, L. Troiano, M. G. Fernandez, M. Pinti, J. Pedrazzi, C. Franceschi and A. Cossarizza, Cytometry, 2000, 40, 189-197.

41 C. Li, M. Yu, Y. Sun, Y. Wu, C. Huang and F. Li, J. Am. Chem. Soc., 2011, 133, 11231-11239. 